\title{
Measuring the effect of Brand Personality on Brand Loyalty: Mediating Role of Customer Satisfaction
}

\author{
Muhammad Salih Memon ${ }^{1}$, Mansoor Ahmed Soomro ${ }^{2 *}$, Muhammad Asif channa ${ }^{3}$, Benazir Solangi ${ }^{4}$ \\ ${ }^{1}$ Associate Professor, Institute of Business Administration, Shah Abdul Latif University Khairpur, Sindh, Pakistan \\ $2^{*}$ Assistant Professor, Department of Business Administration, Mohtarma Benazir Bhutto Shaheed Sindh University Campus, \\ Dadu, Pakistan mansoor.soomro@usindh.edu.pk \\ ${ }^{3}$ Assistant ProfessorDepartment of Business Administration, Mohtarma Benazir Bhutto Shaheed Sindh University Campus, Dadu, \\ Pakistan \\ ${ }^{4}$ Researcher, Shah Abdul Latif University, Khairpur
}

\begin{abstract}
Purpose - This study conceptualizes the measuring effect of brand personality along with its five dimensions on brand loyalty with the help of customer satisfaction played the role of mediation among the users of Samsung cell-phones.

Design/MethodologyApproach - The study was in quantitative nature. Data was collected from 418 respondents from the different cities of Sindh like Karachi, Hyderabad, Mirpurkhas, and Sukkur through a survey questionnaire, and data was analyzed through smart PLS Software by applying the Structural Equation Modeling (SEM) technique.

Findings - The findings executed that the keeping in view all other things constant one unit change in brand personality cause a change of 0.919 in customer satisfaction, one unit change in brand personality cause a change of 0.879 in brand loyalty and one unit change in customer satisfaction will cause a change of 0.095 in brand loyalty. As the results suggest that the brand personality has a positive strong relation with brand loyalty directly, here customer satisfaction has played the role of partial mediator between brand personality and brand loyalty at very weak relations with brand loyalty. Thus increasing error is at the minimum position because all the values are lying on the positive axis.

Practical Implications - This study strongly assists marketers to improve customer loyalty strategies. This study has figured out the clear picture for marketers that if the customers perceive highly based on brand personality so it would be nice for marketers to strengthen the brand personality attributes for brand loyalty.

Origionality/Value - This study is not only emphasized the brand personality but also put an in-depth eye on customer satisfaction. In this study, customer satisfaction played a partial mediating role because of the positive and strong relationship found between brand personality and brand loyalty.
\end{abstract}

Keywords:

Brand Personality, Brand Loyalty, Customer satisfaction.

Article Received: 18 October 2020, Revised: 3 November 2020, Accepted: 24 December 2020

\section{Introduction}

Branding ultimately works as a signal. It permits consumers to rapidly perceive a product as one they know about or one they like. It goes about as a memory sign, permitting buyers to retrieve important information from memory. This data might be about the experience of the brand, brand recognition, or brand associations. The data we have put away about brands is vital in managing our decisions (Chovanová et al., 2015). Branding has gotten one of the most significant characteristics of business strategy. Branding is key to making value for customers, in maintaining and creating a competitive advantage it is not only just image but also considered as a key tool (Holt, D. B. 2015).

Brand personality is the reflection of human attributes in the brands, generated through famous figures (Grisaffe, D. B., \& Nguyen, H. P, 2011). As human personality plays the role of attention as same in brand personality demonstrates the brand's attention in the consumer minds (Blythe, J. 2007).. Brand personality is the major source of core competency. Companies must set aside all the personality traits in one brand, mostly only one attribute of the brand reflects only a single 
personality trait (Ang, S. H., \& Lim, E. A. C. 2006). Brand personality got birth with the entrance of celebrities in commercial advertising as Shahid Afridi in Head \& Shoulder, Salman Khan in Thumbs Up, various actresses in Lux (Fournier, S., 1998). Customers prefer those brands often matches with their personality or with their ideal personality or with their beloved ones, Brand personality has to play multiple roles for creating the perception in consumers' minds (Aaker, et al., 2001).

In marketing literature, consumers are best attracted now through brand personality, used to build a strong relationship between customers and brand, brand personality advocates brand satisfaction leads to brand loyalty (Govers, P. C., \& Schoormans, J. P. 2005). Brand personality lonely nothing to determine brand loyalty, customer satisfaction always found in a linear relationship with brand loyalty as well (Faullant, et al., 2008). Many studies have strongly argued that customer satisfaction has played the role of a bridge between brand personality and brand loyalty (Jang et al,. 2008). In Cell-Phones the appearance, size, style, color reflects the human personality, and that ultimately creates brand loyalty among customers (Chaudhuri, A., \& Holbrook, M. B, 2001). Various theories suggest that brand loyalty is the outcome of customer satisfaction and brand performance that urge customers to buy repeatedly. Brand loyalty mostly considered as the variable used to show the company's profitability and consumers' behavior towards company brands, hold customers bonded to purchase again, and again the company's originated brands (Loureiro et al., 2017)

\subsection{Research Gap}

Although a sufficient amount of research conducted in the field of brand management, various authors suggested various constructs for brand personality, brand loyalty, and customer satisfaction. Tupes \& Chiristal (1958), Norman, Kassarjian, Keller, Fournier, J.L Aker (1997), as a single dimension, four dimensions, and five dimensions but the meaning and applications of the concepts vary country to country even brand to brand. But yet not such dimensions measured among cell-phone users in Pakistan. Motivated by this logic, this study will be able to fill this gap by advocating the research aims among cell phone users. Further, the research has highlighted the significant contribution of how brand personality and brand loyalty influence customer satisfaction.

\subsection{Research Aims}

This study aims to address the role of customer satisfaction in determining the effect of brand personality on brand loyalty in cell-phones as a mediating factor by advocating the following research aims.

1. To study the relationship between brand personality and customer satisfaction.

2. To elaborate on the mediating role of customer satisfaction in brand personality and brand loyalty.

3. To ascertain the relationship between brand personality and brand loyalty.

4. To investigate the relationship between customer satisfaction and brand loyalty.

\subsection{Research Questions}

Despite considering the significant issues with previous research studies this study tried to answer the following research questions.

Q1: How does brand personality-related with customer satisfaction?

Q2: What is the role played by customer satisfaction in measuring the effect of brand personality on brand loyalty?

Q3: What is the relationship between brand personality and brand loyalty?

Q4: How does customer satisfaction relate to brand loyalty? 


\section{Literature Review}

\subsection{Brand Personality}

In our daily life, we are surrounded by a large number of brands. From dawn to down whatever we see, we consume, we eat, we wear, we feel, we drink, all about brands (Aaker, J. L. 1997). A brand is a "name, term, sign, symbol, or design, or a combination of them, intended to identify the goods and services of one seller or group of sellers and to differentiate them from those of competition". Brand personality "as a set of human characteristics associated with the brand". Brands are playing the role of intangible assets used to satisfy all stakeholders through their performance (Freling, T. H., \& Forbes, L. P., 2005). In marketing academic and empirical research studies, brand personality found an interesting and most researched topic (Aaker et al., 2004) Brand personality associated with products and services core benefits perceived performance in consumers' mindset but in a global setting, it became a challenge for companies to design a brand because the market is enough to full of brands (Acharya, A., \& Gupta, M., 2018). Brand personality can be best used to identify the bonding between brand performance and its outcomes (Eisend, M., \& StokburgerSauer, N. E., 2013). Brand personality is a unidimensional construct (Bosnjak et al., 2007). Theoretically, brand personality has three dimensions (Sincerity, Competence, and Status (Avis et al., 2012). Brand personality has multidimensional facets ( four or five) namely Sincerity, Competence, Excitement, Sophistication, Ruggedness (Aaker, J. L., 1997). Literature suggests that the same authors worked on the same dimensions in different cultures found different results and concluded with changed brand personality constructs as in "Japan Ruggedness replaced as peacefulness" (Von Wallpach et al., 2017). Brand personality has achieved a symbolic image in consumer and marketing research. As brands are designed in such a manner that satisfies human needs in such a manner that they feel it is born only for fulfilling their needs, brand personality can't be separated from the human characteristics (Bilgili, B., \& Ozkul, E. 2017). After all measuring brand personality in different cultures, different mindsets, different regions globally, in different products and service consumption levels, roles, statuses, academically and as a marketing practice, the brand personality found a multidimensional construct with more than five constructs, although up to fifteen but not endless (Kotler, P., \& Keller, K. L., 2015).

\subsection{Brand Personality and Customer Satisfaction}

Satisfaction has yet not got a proper definition. The satisfaction found the very old and most studied concept in research. In marketing literature enough studies conducted on the concept of customer satisfaction by applying various marketing practices and strategies because the main orbit of marketing revolves around customer satisfaction (Thier, K., 2020). A customer is defined as "a person who buys goods or services from a shop or business (Oxford Dictionaries)." Satisfaction is described as "a person's feelings of pleasure or disappointments that result from comparing a product or service's perceived performance (or outcome) to expectation" (Roth, S., \& Bösener, K., 2015). All the marketing strategies are only formulated to gain a competitive advantage in marketing and that is only possible to the large share of customers if they found satisfied (Deng et al., 2010). Bill Gates (a US businessman) once said: "Your most unhappy customers are your greatest source of learning." Companies from diverse industries can get a larger market share if they become customer-oriented (Aspizain, C., 2016). Customer satisfaction in brand loyalty is a twofold concept: Specific Transaction based purchases and overall experience of brand performance over a streamline of purchases (Armstrong et al., 2014). When cumulative customer satisfaction shows outcomes towards brand personality, it leads to brand loyalty. Customer satisfaction with brand personality 
depends on experiences and emotions associated with customer personality and needs (Kimemia, R. W., 2016). The Product's real performance and performance expectations emotionally judged by customers are known as customer satisfaction (Mohammad, A. A. S., 2017). Brand personality enables customers to differentiate it from its competing brands by feeling and sensing appearance and performance (Maehle et al., 2011). A bond between consumers and marketers built with the help of a brand personality. Through brand personality, a consumer feels that the company has produced a certain brand only by focusing his/her personality traits (Hussein, A. S., 2018). Brand personality accompanied by the product quality and values impacts positively on consumer behavior to purchase and being loyal to a particular brand (Michael, R. S., 2013). Major literature studies concluded that mostly brand personality found in a positive relationship with customer satisfaction.

\section{H1: Brand Loyalty has a positive and significant relationship with customer satisfaction.}

\subsection{Customer Satisfaction and Brand Loyalty}

Literature suggests that customer satisfaction and brand loyalty always found in goods a few in services. Brand loyalty defined as the repeating behavior of customers to re-buy the same brand of a particular product. Brand loyalty plays an important role in consumer behavior. Brand Loyalty considered an outcome of positive consumer behavior, it helps consumers to purchase a product for a long period (Iglesias et al., 2011). Customer satisfaction is not ended for companies to capture the value and to achieve organizational goals, companies have to survive in long run in this regard, brand loyalty plays the role of the company's existence and identification in the market (Awan, A. G., \& Rehman, A. U., 2014). Brand loyalty works as a synonym for customers' commitment towards brands. Customers analyze products based on intrinsic and extrinsic cues: intrinsic cues refer to actual product performance while extrinsic cues refer to brand personality that leads to brand loyalty (McMullan, R., 2005). Brand loyalty and customer satisfaction together are considered as marketing objectives in marketing era, by applying various application customer satisfaction always found the best predictor of brand loyalty (Oliver, R. L., 1999). To target customer satisfaction as an objective is not an end, it must be focused on brand loyalty, profit gain attributes. In the early 2000s, customer satisfaction had got importance only as a tool to achieve a strategic approach but now it turned into a tool to develop and gain other strategic goals like loyalty, sustainability, core competency. Now companies are trying to capture more brand loyalty rather than only customer satisfaction or short term profitability. Brand loyalty generated through the positive commitment of customers towards products. Brand Loyalty is therefore related to a customer's preference and attachment to a brand. It may occur due to a long history of using a product and trust that has developed as a consequence of the long usage (Yoo, B., \& Donthu, N., 2001).

\section{H2: Brand personality has a positive and significant relationship with customer satisfaction.}

\subsection{Brand Personality and Brand Loyalty}

Brand loyalty has been originated by Chaudhuri, A., \& Holbrook, M. B. (2001), major focusing on loyalty towards the company's products and services. Oliver defined brand loyalty as "a deeply held commitment to rebuy or patronize a preferred product/service consistently in the future, thereby causing repetitive same-brand or same brand-set purchasing, despite situational influences and marketing efforts having the potential to cause switching behavior" (Akin, M., 2017) defined brand loyalty from an attitudinal perspective as "the tendency to be loyal to a focal brand, which is demonstrated by the intention to buy the brand as a primary choice" (Datta, P. R., 2003) argued that "attitudinal brand loyalty includes a degree of 
dispositional commitment in terms of some unique value associated with the brand" (p. 82). They can do it through strong advertising and marketing campaigns and the provision of highquality services or products. Brand personality directly affects brand loyalty by focusing on the behavioral attitude of customers. Competency and excitement always found more acceptable among customers over conventionality and ruggedness ( Aaker et al., 2001) Brand personality considered a strategic instrument used to generate brand loyalty, brand personality had always advocated a positive influence on brand loyalty (Ang, S. H., \& Lim, E. A. C., 2006). To maintain a stable market share marketers need the support of loyal customers resulting from brand loyalty. Brand personality helps loyal consumers to different brands as compared to competitors (Kim, R. B., \& Zhao, M., 2014). Brand personality contributes to the sensory decisions of consumers to be loyal (Nysveen, H., \& Pedersen, P. E., 2014). Brand loyalty is a post-purchase concept. Brand personality as a predictor of brand loyalty reduces marketing and advertising cost for marketers (Ivens, B., \& Valta, K. S., 2012). Brand personality accompanied by other branding attributed to brand awareness, brand affect, brand trust has found always the positive and significant determinant of brand loyalty (Awang et al., 2015) Bonding between brand loyalty and brand performance generated by brand personality (Umar et al., 2015).

\section{H3: Brand personality has a positive and significant relationship with brand loyalty.}

\subsection{Customer Satisfaction as Mediating Factor}

When the independent variable shows less influence on dependent variable mediating variable supports to show significant influence. Customer satisfaction always found as a significant ingredient of customer loyalty towards brands (Aaker, J. L., 1997). It mostly used as a mediating variable to measure the effect of various marketing strategies to generate fruitful outcomes (Liang et al.,2011).

\subsection{Theoretical Framework}

The research framework of the study is to determine the role of brand personality in brand loyalty mediated by customer satisfaction among users of Samsung in major cities of Sindh i.e Karachi, Hyderabad, Mirpur Khas, and Sukkur. The framework pertains to the independent and dependent variables. Brand personality is IV, Customer satisfaction plays the role of mediation as well as the dependent variable while brand loyalty is DV measured through CS and BP.

\section{Methods}

\subsection{Procedure and Participants}

The study is quantitative. Although a study designed based on vast literature previously done. Most studies conducted in this context are quantitative and measured based on the primary response generated through a survey questionnaire. The participants of this study were the users of Samsung Cell-Phone in Sindh. A survey questionnaire adopted was applied to collect the response. A total number of 418 questionnaires were filled by the serious and loyal users of Samsung from different cities out of 500 questionnaires distributed.

\subsection{Measurement Scale}

A survey questionnaire consists of three variables Brand Personality further divided into five dimensions measured by using (Jang, et al., 2008) scale consist of 18 facets rather than questions, Customer satisfaction scale of (Safdar, S., \& Lodhi, R. N., 2015) consist of five items and Brand Loyalty scale of (Jöreskog, K. G., 1982) consist of nine items supported by a demographic background of users as well. For respondents' ease and complete understanding, a brief introduction of the purpose of the study added in the questionnaire. A five-point Likert Scale used to quantify the response as $1=$ Strongly Disagree, $2=$ Disagree, 3= Neutral, 4= Agree, and 5= Strongly Agree. The questionnaire was offered in the 2390 
English language and during data collection translated to those users who were unable to understand the English because English is not the native language of users living in Karachi, Hyderabad, Mirpur Khas, and Sukkur. Measurement Scales were consisted of three parts i.e: Brand Personality with five sub-dimensions sincerity with six items, Excitement with four items, Competence with three items, Sophistication with two items and Ruggedness with two items, while customer satisfaction has five items and brand loyalty has nine items respectively.

\subsection{Analysis}

In quantitative research, the standard response analyzed through certain social sciences applications. Analysis conducted through data coding, techniques applied, results in the generation, and finally interpretation of results. At the very first collected data inputted into SPSS for easy data transformation. For measuring the effect of latent variables and their loadings, measuring reliability and validity, hypotheses test the PLSSEM technique used (Nunnally, J. C., 1978). Literature suggests that measuring the effect through mediation PLS-SEM has been found best application to draw all the desired measures.
Before moving to measure the latent variables construct reliability and composite reliability were conducted, and construct validity was extracted by applying factor loading criteria at the minimum value 0.70 .

\section{Study Findings}

The Partial Least Square-Structural Equation Model (PLS-SEM) techniques used to draw empirical results of the study.

\subsection{Loadings, Reliability, Validity and Average Variance Extracted}

considering internal consistency the composite reliability should be greater than 0.70 (Nunlay, 1978) Specifically, all three variables have composite reliability value greater than its critical value 0.70 , supporting the internal consistency evidence. Brand loyalty has greater than 0.933, brand personality has greater than 0.958 and the customer satisfaction has greater than 0.910 advocating that the collected response is enough consistent for further analysis. The convergent validity of the scale was measured with the help of loadings and AVE values, as shown in the table the loadings, and AVE values are greater than 0.50 which evident as the scale is validated to processed ahead.

Table 1. Measurement Model

\begin{tabular}{lllll}
\hline Constructs & Items & Loadings & CR & AVE \\
\hline Brand Personality & BP1 & 0.853 & 0.958 & 0.640 \\
& BP2 & 0.859 & & \\
& BP3 & 0.876 & & \\
& BP4 & 0.730 & & \\
& BP5 & 0.848 & & \\
& BP6 & 0.779 & & \\
& BP7 & 0.727 & & \\
& BP8 & 0.818 & & \\
& BP9 & 0.799 & & \\
Customer Satisfaction & BP10 & 0.768 & & \\
& CS1 & 0.779 & 0.910 & 0.670 \\
& CS2 & 0.788 & & \\
& CS3 & 0.859 & & \\
& CS4 & 0.830 & & \\
\hline
\end{tabular}




\begin{tabular}{lllll}
\hline & CS5 & 0.833 & & \\
CS6 & 0.754 & & \\
CS7 & 0.743 & & \\
CS8 & 0.792 & & \\
CS9 & 0.764 & & \\
Brand Loyalty & CS10 & 0.692 & & \\
& BL1 & 0.801 & & \\
BL2 & 0.8635 & & \\
BL3 & 0.796 & & \\
BL4 & 0.819 & & \\
BL5 & 0.786 & & \\
BL6 & 0.755 & & \\
BL7 & 0.762 & & \\
BL8 & 0.789 & \\
BL9 & 0.820 & \\
\hline
\end{tabular}

Table 2. Discriminant Validity (HTMT)

\begin{tabular}{lccc}
\hline Constructs & 1 & 2 & 3 \\
\hline 1. Brand Personality & & & \\
2. Customer Satisfaction & 0.758 & \\
3. Brand Loyalty & 0.797 & 0.818 & \\
\hline
\end{tabular}

The above table shows the results of discriminant validity (DV) was verified, which indicates the extent to which a construct differs from other constructs within the model. We compared the square-root of the AVE with the correlations among constructs. In cases where the square roots of the AVE values are higher than the correlation values in the respective row and column, we can confirm that the measures are discriminant. Table 2 shows that the square roots of the AVEs are higher than the row and column values; as such DV is confirmed.

Table 3. Hypothesis Testing

\begin{tabular}{llllllllll}
\hline Hypothesis & Relationship & Std & Std & T- & P- & BCILL & BCIUL & $f^{2}$ & VIF \\
& & Beta & Error & Value & Values & & & & \\
\hline H1 & BP -> BL & 0.900 & 0.029 & 30.934 & 0.000 & 0.843 & 0.952 & 1.887 & 2.420 \\
H2 & BP -> CS & 0.919 & 0.009 & 107.213 & 0.000 & 0.898 & 0.932 & 5.399 & 1.607 \\
H3 & CS -> BL & 0.072 & 0.031 & 2.332 & 0.000 & 0.016 & 0.128 & 1.032 & 1.912 \\
\hline
\end{tabular}

In the next stage, we proceeded with the path analysis to test the three hypotheses generated for this study. Table 3 presents the results. We tested the direct effects of the main constructs on brand 
loyalty through customer satisfaction. Brand personality $(\beta=0.900, \quad \mathrm{P}$-value $=0.000)$, Brand Personality $(\beta=0.919, \quad \mathrm{P}$-value $=0.000) \quad$ and customer satisfaction $(\beta=0.072, \mathrm{P}$-value $=0.000)$ were positively related to brand loyalty. Thus $\mathrm{H} 1$, $\mathrm{H} 2$, and $\mathrm{H} 3$ were supported.

\section{Conclusion and Discussion}

The study was aiming to measure the effects of brand personality on brand loyalty with the help of customer satisfaction towards Samsung cellphone users in different cities of Sindh. The study revealed the behavior and perception of Samsung customers in different cities of Sindh. In-depth picture of the literature and statistical findings shown in this study. The study has achieved all the proposed aims and well addressed the research questions. Statistical findings revealed that all the hypotheses were found supportive in the light of prior literature.

Quantitative research accompanied by multiple statistical techniques applied through a structured questionnaire. Responses and propositions were reflected in the prior literature through PLS-SEM. The findings revealed that the brand personality has a positive and significant impact on brand loyalty, results also provided a way to customer satisfaction being used as a mediator between brand personality and brand loyalty. In this study, customer satisfaction has played the role of partial mediation between brand personality and brand loyalty.

According to the findings of this study, the brand personality has a positive and significant effect on customer satisfaction and brand loyalty, on the other hand, customer satisfaction has also a positive and significant relationship with brand loyalty. Brand loyalty was well predicted by brand personality accompanied by customer satisfaction. Statistical findings also validated the proposed hypotheses and model with the prior literature based on accepted value for AVE. Findings put an interesting insight that its not necessary that all the brand personality constructs being applied to all the types of customers and all the brands to the same extent. Some of the constructs of Sincerity, Competence, and brand loyalty were not contributed to the measurement.

This study strongly recommends the Samsung company that never ignores customer perception and behavior while expecting brand loyalty from customers through brand personality. Marketers should also put an eye on brand personality dimensions as well.

\section{Limitations and Future Research Directions}

Almost every type of research cannot be an end in theoretical, conceptual, and measurement contexts. Limitations of the study provide a plate form for innovation and invention context. None can be perfect in all contexts of research. The limitations of this study will be ingredients for future researchers in the following contexts.

\subsection{Comparative Study}

This study by nature was unidimensional in theoretical, conceptual, measurement, unit of analysis, targeted brand context. In this regard future studies can be best conducted by comparing the Samsung brands with other Andriod cellphones like apple, oppo, Q-mobile, Nokia, etc. also by comparing the customers of different cultures of Sindh as well Pakistan or globally. In this study conducted in the product context, future studies may be conducted for measuring brand loyalty among service brands as well.

\subsection{Mixed Methodology}

As this study was conducted through a single research method, future research can be conducted by using mixed methods qualitative and quantitative as a well or qualitative method only. Different instruments can be used to collect the response.

\subsection{Longitudinal Study}

The major constraints for this study were time and cost so this study was conducted only cross- 
sectional. In the same context, this study can be conducted as a longitudinal for vast literature and for providing better negotiable results.

\subsection{Brand Variables}

This study was only conducted by focusing only two constructs of brand management i-e: brand personality and brand loyalty. Future research may be conducted in other constructs of brand management as brand trust, brand awareness, brand experience, brand satisfaction and so on.

\section{References}

[1] Aaker, J. L. (1997). Dimensions of brand personality. Journal of marketing research, 34(3), 347-356, doi:https://doi.org/10.1177/002224379703 400304

[2] Aaker, J. L. (1997). Dimensions of brand personality. Journal of marketing research, 34(3), 347-356, doi:https://doi.org/10.1177/002224379703 400304

[3] Aaker, J. L., Benet-Martinez, V., \& Garolera, J. (2001). Consumption symbols as carriers of culture: A study of Japanese and Spanish brand personality constructs. Journal of personality and social psychology, 81(3), 492, 492-508, 10. 1037//0022-3514.g 1.3.492

[4] Aaker, J. L., Benet-Martinez, V., \& Garolera, J. (2001). Consumption symbols as carriers of culture: A study of Japanese and Spanish brand personality constructs. Journal of personality and social psychology,81(3), 492-508, https://doi.org/10.1037/0022-

3514.81.3.492

[5] Aaker, J., Fournier, S., \& Brasel, S. A. (2004). When good brands do bad. Journal of Consumer research,31(1), 1-16, https://doi.org/10.1086/383419

[6] Acharya, A., \& Gupta, M. (2018). Green
Brand Personality: Its Relevance to the Green Marketing Practices. In Driving Green Consumerism Through Strategic Sustainability Marketing (pp. 155-168). IGI Global, 10.4018/978-1-5225-29125.ch009

[7] Akin, M. (2017). The impacts of brand personality on brand loyalty: A research on automobile brands in Turkey. International Journal of Marketing Studies, 9(2), 134-145, 10.5539/ijms.v9n2p134

[8] Ang, S. H., \& Lim, E. A. C. (2006). The influence of metaphors and product type on brand personality perceptions and attitudes. Journal of advertising, 35(2), 3953 ,

https://doi.org/10.1080/00913367.2006.10 639226

[9] Ang, S. H., \& Lim, E. A. C. (2006). The influence of metaphors and product type on brand personality perceptions and attitudes. Journal of advertising, 35(2), 3953 ,

https://doi.org/10.1080/00913367.2006.10 639226

[10] Armstrong, G., Adam, S., Denize, S., \& Kotler, P. (2014). Principles of marketing. Pearson Australia.

[11] Aspizain, C. (2016). The effects of service quality and corporate rebranding on brand image, customer satisfaction, brand equity, and customer loyalty: study in advertising company at tvOne. Russian Journal of Agricultural and Socio-Economic Sciences, 60(12), https://doi.org/10.18551/rjoas.2016-12.26

[12] Avis, M., Aitken, R., \& Ferguson, S. (2012). Brand relationship and personality theory: metaphor or consumer perceptual reality?. Marketing Theory, 12(3), 311331 , https://doi.org/10.1177/147059311245139 6 
[13] Awan, A. G., \& Rehman, A. U. (2014). Impact of customer satisfaction on brand loyalty: An empirical analysis of home appliances in Pakistan. British Journal of Marketing Studies, 2(8), 18-32.

[14] Awang, Z., Afthanorhan, A., \& Asri, M. A. M. (2015). The parametric and nonparametric approach in structural equation modeling (SEM): The application of bootstrapping. Modern Applied Science, 9(9), 58, doi:http://dx.doi.org/10.5539/mas.v9n9p58

[15] Bilgili, B., \& Ozkul, E. (2015). Brand awareness, brand personality, brand loyalty, and consumer satisfaction relations in brand positioning strategies (A Torku brand sample). Journal of Global Strategic Management Volume, 9(2), 10.20460/JGSM.2015915576

[16] Blythe, J. (2007). Advertising creatives and brand personality: A grounded theory perspective. Journal of Brand Management, 14(4), 284-294, 10.1057/palgrave.bm.2550071

[17] Bosnjak, M., Bochmann, V., \& Hufschmidt, T. (2007). Dimensions of brand personality attributions: a personcentric approach in the German cultural context. Social Behavior and Personality: an international journal, 35(3), 303-316, https://doi.org/10.2224/sbp.2007.35.3.303

[18] Chaudhuri, A., \& Holbrook, M. B. (2001). The chain of effects from brand trust and brand affect to brand performance: the role of brand loyalty. Journal of Marketing, 65(2), 81-93, 10.1509/jmkg.65.2.81.18255

[19] Chaudhuri, A., \& Holbrook, M. B. (2001). The chain of effects from brand trust and brand affect to brand performance: the role of brand loyalty. Journal of Marketing, 65(2), 81-93. doi:https://doi.org/10.1509/jmkg.65.2.81.1
8255

[20] Chovanová, H. H., Korshunov, A. I., \& Babčanová, D. (2015). Impact of the brand on consumer behavior. Procedia Economics and Finance, 34, 615-621., https://doi.org/10.1016/S22125671(15)01676-7

[21] Datta, P. R. (2003). The determinants of brand loyalty. Journal of American Academy of Business, 3(1/2), 138-144.

[22] Deng, Z., Lu, Y., Wei, K. K., \& Zhang, J. (2010). Understanding customer satisfaction and loyalty: An empirical study of mobile instant messages in China. International journal of information management, 30(4), 289-300, https://doi.org/10.1016/j.ijinfomgt.2009.10 .001

[23] Eisend, M., \& Stokburger-Sauer, N. E. (2013). Brand personality: A meta-analytic review of antecedents and consequences. Marketing Letters, 24(3), 205-216.Keller, K. L. (1995). Strategic Brand Management, New Jersey, PrenticeHall, https://doi.org/10.1007/s11002-0139232-7

[24] Faullant, R., Matzler, K., \& Füller, J. (2008). The impact of satisfaction and image on loyalty: the case of Alpine ski resorts. Managing Service Quality: An International Journal, 10.1108/09604520810859210

[25] Fournier, S. (1998). Consumers and their brands: Developing relationship theory in consumer research. Journal of consumer research, 24(4), 343-373, 10.1086/209515

[26] Freling, T. H., \& Forbes, L. P. (2005). An examination of brand personality through methodological triangulation. Journal of brand management, 13(2), 148-162, https://doi.org/10.1057/palgrave.bm.25402 54 
[27] Govers, P. C., \& Schoormans, J. P. (2005). Product personality and its influence on consumer preference. Journal of Consumer Marketing, https://doi.org/10.1108/073637605106053 08

[28] Grisaffe, D. B., \& Nguyen, H. P. (2011). Antecedents of emotional attachment to brands. Journal of business research, 64(10), 1052-1059, 10.1016/j.jbusres.2010.11.002

[29] Holt, D. B. (2015). Brands and Branding. Cultural Strategy Group.[online] Available on HTTP. testconso. Typepad. com/files/brands-and-brandingcsg2. pdf.

[30] Hussein, A. S. (2018). Effects of brand experience on brand loyalty in Indonesian casual dining restaurant: Roles of customer satisfaction and brand of origin. Tourism and hospitality management, 24(1), 119132, https://doi.org/10.20867/thm.24.1.4

[31] Iglesias, O., Singh, J. J., \& Batista-Foguet, J. M. (2011). The role of brand experience and affective commitment in determining brand loyalty. Journal of Brand Management, 18(8), 570-582, http://10.1057/bm.2010.58.

[32] Ivens, B., \& Valta, K. S. (2012). Customer brand personality perception: A taxonomic analysis. Journal of Marketing Management, 28(9-10), 1062-1093, https://doi.org/10.1080/0267257X.2011.61 5149

[33] Jang, H., Olfman, L., Ko, I., Koh, J., \& Kim, K. (2008). The influence of on-line brand community characteristics on community commitment and brand loyalty. International Journal of Electronic Commerce, 12(3), 57-80, 10.1109/HICSS.2007.544

[34] Jang, H., Olfman, L., Ko, I., Koh, J., \& Kim, K. (2008). The influence of on-line brand community characteristics on community commitment and brand loyalty. International Journal of Electronic Commerce, 12(3), 57-80, doi:https://doi.org/10.2753/JEC10864415120304

[35] Jöreskog, K. G. (1982). The LISREL approach to causal model-building in the social sciences. Systems under indirect observation, Part I, 81-100.

[36] Kim, R. B., \& Zhao, M. (2014). Chinese Consumers'brand Loyalty For Consumer Products: Importance Of Brand Personality As Major Antecedent Of Brand Loyalty. Asian Academy of Management Journal, 19(1),

[37] Kimemia, R. W. (2016). Effects of corporate branding on customer satisfaction; a survey of licensed microfinance institutions in Nairobi, Kenya. International Journal of Social Science and Information Technology, 2(9), 1024-1034.

[38] Kotler, P., \& Keller, K. L. (2015). Marketing management, global edition. Pearson Education UK.

[39] Liang, T. P., Ho, Y. T., Li, Y. W., \& Turban, E. (2011). What drives social commerce: The role of social support and relationship quality. International journal of electronic commerce, 16(2), 69-90, DOI: $10.2307 / 23106394$

[40] Loureiro, S. M. C., Sarmento, E. M., \& Le Bellego, G. (2017). The effect of corporate brand reputation on brand attachment and brand loyalty: The automobile sector. Cogent Business \& Management, 4(1), 1360031, https://doi.org/10.1080/23311975.2017.13 60031 
[41] Maehle, N., Otnes, C., \& Supphellen, M. (2011). Consumers' perceptions of the dimensions of brand personality. Journal of Consumer behavior, 10(5), 290-303, https://doi.org/10.1002/cb.355

[42] McMullan, R. (2005). A multiple-item scale for measuring customer loyalty development. Journal of Services Marketing, 19(7), 470-481, https://doi.org/10.1108/088760405106259 72

[43] Michael, R. S. (2013). Consumer Behaviour: Buying, Having, Being. PEARSON AUSTRALIA.

[44] Mohammad, A. A. S. (2017). The impact of brand experiences, brand equity, and corporate branding on brand loyalty: Evidence from Jordan. International journal of academic research in accounting, finance and management sciences, 7(3), 58-69.

[45] Nunnally, J. C. (1978). Psychometric Theory: $2 d$ Ed. McGraw-Hill.

[46] Nysveen, H., \& Pedersen, P. E. (2014). Influences of cocreation on-brand experience. International Journal of Market Research, 56(6), 807-832., DOI:10.2501/IJMR-2014-016

[47] Oliver, R. L. (1999). Whence consumer loyalty? Journal of Marketing. 1999 63s, 33-44, doi:https://doi.org/10.1177/002224379703 400304.

[48] Roth, S., \& Bösener, K. (2015). The influence of customer satisfaction on customer price behavior: literature review and identification of research gaps. Management Review Quarterly, 65(1), 1-33, https://doi.org/10.1007/s11301-014-0105-
9

[49] Safdar, S., \& Lodhi, R. N. (2015). Mediating impact of corporate entrepreneurship on the relationship among job satisfaction, citizenship behavior, and organizational commitment: Evidence from Pakistan banking employees. Global Management Journal for Academic \& Corporate Studies, 5(1), 99.

[50] Thier, K. (2020). Springboard Story: Mit Geschichten Menschen gewinnen. In Narrative Organisationen (pp. 185191). Springer Gabler, Berlin, Heidelberg.

[51] Umar, A., Bahrun, R., \& Sukati, I. (2015). Customer satisfaction as mediator between price, trust, and brand loyalty: A case study from Malaysia. Malaysia: Universiti Teknologi Malaysia. Tersedia di: https://www. researchgate. net/publication/327574473_Customer_sati sfaction_as_mediator_between_price_trus t_and_brand_loyaltyCase_study_from_Ma laysia.

[52] Von Wallpach, S., Voyer, B., Kastanakis, M., \& Mühlbacher, H. (2017). Co-creating stakeholder and brand identities: Introduction to the special section. Journal of Business Research, 70, 395-398.Gary Davies, J. I.-M. (2018). Brand personality: theory and dimensionality. Journal of Product \& Brand Management, https://doi.org/10.1016/j.jbusres.2016.08.0 28

[53] Yoo, B., \& Donthu, N. (2001). Developing and validating a multidimensional consumer-based brand equity scale. Journal of business research, 52(1), $1-14$, DOI:10.1016/S01482963(99)00098-3 